\section{Akuntansi Forensik dan Fenomena Korupsi Politik}

\author{
Bambang Arianto \\ Peneliti LPPM Univeritas Nahdlatul Ulama \\ Yogyakarta, Yogyakarta, Indonesia \\ *Korespondensi Penulis Email : \\ ariantobambang@unu-jogja.ac.id
}

\begin{abstract}
Abstrak
Artikel ini menjelaskan peran akuntansi forensik dalam pemberantasan korupsi politik. Akuntansi forensik juga dikenal sebagai audit forensik yang merupakan penugasan khusus untuk mengatasi kecenderungan praktik fraud dalam ranah akuntansi. Dalam artikel ini audit forensik menguraikan beberapa indikator penyebab terjadinya kecurangan (fraud) dalam korupsi politik yaitu faktor; tekanan (pressure), kesempatan (opportunity), rasionalisasi (rasionalization), kompetensi (competency), dan arogansi (arogance). Dalam konteks ini, tahapan akuntansi forensik meliputi; audit investigasi, audit forensik dan ligitasi yang bertujuan mengatasi kasus korupsi politik. Penelitian ini menggunakan metode kualitatif dengan pendekatan studi pustaka serta mengumpulkan data-data dan dokumen yang terkait. Artikel ini berpendapat bahwa akuntansi forensik sangat efektif mendeteksi dan berperan dalam proses pemberantasan praktik korupsi politik. Artikel ini juga berpendapat bahwa akuntansi forensik bisa mendorong literasi anti fraud dalam partai politik melalui penerapan sistem whistleblowing.
\end{abstract}

Kata Kunci: Akuntansi Forensik, Korupsi Politik, Literasi Anti-Fraud

\section{Forensic Accounting and the Political Corruption Phenomenon}

\begin{abstract}
This article explains the role of forensic accounting in eradicating political corruption. Forensic accounting is also known as forensic audit which is a special assignment to overcome the tendency of fraud practices in the realm of accounting. In this article the forensic audit outlines several indicators that cause fraud in political corruption, namely factors; pressure, opportunity, rationalization, competency, and arrogance. In this context, the stages of forensic accounting include; investigative audits, forensic audits and litigations aimed at addressing cases of political corruption. This study uses a qualitative method with a literature study approach and collects data and related documents. This article argues that forensic accounting is very effective in detecting and contributing to the process of eradicating the practice of political corruption. This article also believes that forensic accounting can encourage anti-fraud literacy in political parties through the application of a whistleblowing system.
\end{abstract}

Keywords: Forensic Accounting, Political Corruption, Anti-Fraud Literacy 


\section{A. PENDAHULUAN}

Apresiasi patut diberikan kepada Komisi Pemberatasan Korupsi (KPK) yang telah banyak berhasil mencegah dan memberantas praktik korupsi politik. Adanya berbagai bentuk operasi tangkap tangan, semakin membuktikan bahwa lembaga antirusuah ini sangat memberikan kontribusi nyata dalam memberantas praktik korupsi-suap di semua sektor pemerintahan. Dalam konteks ini fraud (kecurangan) yang dijelaskan hanya pada tataran ranah korupsi politik yang memang banyak melibatkan para politisi dan kepala daerah. Meski demikian, dengan berbagai modus operandi yang telah dilakukan, semakin mengkonfirmasi bahwa praktik tindak pidana korupsi politik semakin banyak terjadi, meskipun lembaga anti-rasuah sebagai pengawas dan pencegah telah berdiri sejak 1999.

Bila mengutip kajian Quah (2013) bahwa lembaga anti-rasuah seperti KPK inilah yang dapat memberantas korupsi seperti di Singapura dan Hongkong. Dengan demikian, eksistensi KPK akan semakin menjadi penentu masa depan pemberantasan korupsi di Indonesia. Hal itu diperkuat oleh ulasan Girling (1997) yang menilai bahwa korupsi bukan semata-mata persoalan moral individual, melainkan problem yang telah melekat dalam struktur ekonomipolitik, sehingga dalam banyak hal praktik korupsi semakin terbentuk secara terstruktur dan sistematis. Akan tetapi dalam konteks ini, partai politik menjadi titik sentral dalam pusaran korupsi politik. Artinya bisa menjadi aktor utama dalam korupsi politik sekaligus bisa ikut berperan penting dalam mencegah terjadinya praktik korupsi politik. Sebab, partai politik menjadi salah satu saluran untuk melahirkan para politisi.

Tetapi faktanya, partai politik di Indonesia hingga saat ini masih belum mampu untuk menjauhkan praktik korupsi politik kepada kadernya. Hal itu bisa dilacak dari semakin meningkatnya penangkapan kepala daerah dan para politisi dari partai politik yang semakin menambah daftar panjang kader partai yang terjerat korupsi. Identifikasi tersebut menjelaskan bahwa partai politik masih belum bisa membimbing kadernya untuk bisa menjadi kader berintegritas yang tentunya terbebas dari praktik korupsi politik. Selain itu partai politik juga belum mampu menjadi garda terdepan dalam upaya pemberantasan korupsi. Sebab, partai politik belum juga dapat mendidik para kadernya agar bisa menjauh dari praktik korupsi suap. Indikator ini membuktikan integritas para pengelola partai politik dalam upaya mengintegrasikan nilai anti-fraud terutama korupsi politik masih sangat jauh.

Apalagi hal itu di perparah dengan mekanisme rekruitmen kader partai politik yang dilakukan masih hanya sekadar mencari kandidat politik yang bisa menyumbang keuangan lebih banyak kepada partai politik. Bukan 
mencari kader yang bisa menyumbangkan integritasnya bagi kemajuan partai politik. Tidak kalah menyedihkan, jelang kontestasi politik 2019, masih banyak partai politik yang mendukung hadirnya wakil rakyat dengan wajah baru serta rekam jejak yang bersih, tetapi justru malah sebaliknya. Partai politik masih menempatkan kader yang merupakan mantan pelaku korupsi untuk menjadi calon anggota legislatif hanya karena calon tersebut memiliki modal yang cukup.

Inilah menyebabkan semakin banyak partai politik tidak lagi bisa melahirkan kader bersih tetapi kader yang asal jadi. Sehingga dampaknya partai politik semakin terlibat dalam praktik korupsi politik yang kemudian membuat kecewa para pendukung maupun simpatisannya. Kegagalan partai politik dalam menanamkan nilainilai anti korupsi inilah yang menyebabkan banyak kader partai politik lupa akan kode etik sebagai kader partai. Meski, semua partai politik memiliki kesamaan untuk anti terhadap korupsi politik. Tetapi, fakta bicara lain, justru banyak kader partai yang menjadi pejabat negara bukan untuk kepentingan publik, melainkan untuk mengejar pundi-pundi uang rakyat. Apalagi, tekanan (pressure) dari partai politik seringkali menuntut kadernya untuk bisa membayar iuran operasional bagi kelangsungan partai. Besarnya pun tergantung dari posisi yang ditempati oleh elit partai politik tersebut.
Eksesnya, banyak kader partai yang menjadi pejabat publik dan wakil rakyat menyalahgunakan kewenangan untuk mencari dana tambahan agar bisa memberikan kontribusi keuangan bagi partainya. Sederat kesalahan dari proses kaderisasi partai politik ini yang harus segera dihentikan. Kalau tidak, gejala ini semakin membuat partai politik akan tetap menjadi lembaga paling terkorup di Indonesia. Sebab, tidak cukup hanya menyodorkan selembar kertas berupa "pakta integritas" di awal rekruitmen, tetapi partai politik juga harus berani bertanggung jawab langsung kepada rakyat untuk tidak lagi diam ketika melihat kadernya melakukan korupsisuap. Tentu tidak baik bila menyalahkan sistem maupun kemelut pendanaan partai yang minim. Tetapi, kesalahan mutlak tentulah harus ditujukan kepada jajaran pengurus partai politik yang tidak bisa memilah kader dengan ketat. Padahal, sederet pelatihan calon kepala daerah maupun sekolah legislatif untuk taat pada fakta integritas partai terus digelar. Artinya, ini bukti nyata bahwa partai politik belum berhasil melaksanakan sistem kaderisasi calon pemimpin secara sistematik, berjenjang dan komprehensif. Sehingga daya tahan partai politik terhadap korupsi politik masih sangat rentan.

Menurut data Indonesian Corruption Watch (ICW) kerugian negara akibat korupsi pada 2018 mencapai $\mathrm{Rp}$ 9,29 triliun. ICW juga mengumpulkan data putusan perkara korupsi yang dikeluarkan oleh 
pengadilan pada tingkat pengadilan negeri, pengadilan tinggi dan Mahkamah Agung. Hasil pemantauan ICW pada tahun 2018 ada 1.053 perkara dengan 1.162 terdakwa yang diputus pada ketiga tingkatan pengadilan (Kompas.com, 2019). Artinya, bisa disimpulkan bahwa korupsi itu merupakan kejahatan luar biasa. Dengan demikian sudah saatnya kita menuntut komitmen partai politik untuk menjadikan korupsi politik sebagai musuh bersama.

Dengan begitu daya tahan partai terhadap godaan sindrom korupsi dan suap politik akan semakin menguat. Selain itu pula publik menantikan seberapa berani partai politik untuk bisa membimbing rakyatnya untuk lebih mengenal rekam jejak para calon wakilnya dihadapan rakyat. Seperti berani membimbing rakyat sebagai alat filter terakhir untuk tidak memilih kader yang terindikasi korupsi dan terus mengedukasi semangat anti korupsi pada kadernya. Dengan melibatkan publik dalam pengawasan partisipatoris, bisa menjadi alat verifikasi bagi partai politik dalam menekan terjadinya korupsi politik. Sebab, saat ini rakyat kian semakin cerdas untuk membedakan mana wakil rakyat yang berintegritas dan mana politisi yang oportunis. Dengan begitu, pelan tetapi pasti partai politik bisa tetap bertahan hidup dan kembali mengagregasi kepentingan rakyat tanpa harus melakukan tindakan korupsi politik.
Dengan melihat identifikasi yang melibatkan banyak kader, membuat diperlukan skema baru yang bisa diambil oleh para pengurus partai politik untuk mencegah dan mendeteksi terjadinya korupsi politik. Salah satunya dengan menggunakan model akuntansi forensik dalam mendeteksi dan pemberantasan korupsi politik. Apalagi akuntansi forensik sudah banyak terbukti mampu mendeteksi dan mencegah terjadi tindakan fraud (kecurangan) terutama korupsi diberbagai sektor. Dengan kata lain, efektivitas audit forensik dalam mendeteksi fraud sangat efektif (Syahputra \& Urumsah, 2019; Mamahit \& Urumsah; Daurrohmah \& Urumsah (2018). Selain itu peran akuntansi forensik sangat berpengaruh terhadap pemberantasan tindak pidana korupsi (Wiratmaja, 2010).

Bahkan untuk mendeteksi terjadinya kerugian negara, KPK juga telah membentuk unit akuntansi forensik. Tujuannya agar para penyidik memiliki kemampuan untuk memaksimalkan upaya pemulihan aset kerugian negara akibat tindak pidana korupsi. Tim akuntansi forensik ini dibentuk untuk meneliti korupsi yang menjerat korporasi penyelenggara negara dan perusahaan swasta dengan kasus dominan berupa gratifikasi. Unit akuntansi forensik tersebut nantinya bertugas membantu kinerja penyidik dalam melakukan audit forensik dan memaksimalkan pengembalian kerugian 
negara akibat kasus korupsi (Kompas.com, 2019).

Selain itu, salah satu peran akuntansi forensik dalam mencegah dan memberantas korupsi politik adalah penarapan sistem whistleblowing. Melalui saluran ini publik bisa ikut berpartisipasti melaporakan segala indikasi fraud (kecurangan) yang dilakukan oleh kader partai politik. Apalagi pemerintah telah berkomitmen untuk mencegah dan memberantas korupsi di lembaga-lembaga pemerintah dengan mengintegrasikan sistem online whistleblowing di 17 kementerian atau lembaga berkerjasama dengan LPSK dan KPK (Gumelar, 2019). Dalam hal ini whistleblowing merupakan sebuah sistem saluran yang dirancang sedemikian rupa agar bisa mengenal lebih dekat berbagai kriteria kecurangan yang dilaporkan. Pelaporan dalam whistleblowing harus memuat prinsip dasar yang meliputi $4 \mathrm{~W}+1 \mathrm{H}$. Pengertian lain mengenai whistleblowing merupakan sebuah pengungkapan oleh anggota organisasi tentang praktik ilegal, tidak bermoral atau tidak sah dibawah kendali atasan mereka, kepada anggota atau organisasi yang dapat mempengaruhi tindakan (Miceli \& Near, 1985).

Artikel ini fokus pada pembahasan peran akuntansi terhadap fenomena korupsi politik dikarenakan studi akuntansi forensik masih sebatas pada korupsi secara umum dan belum secara spesifik mengelaborasi korupsi politik. Dengan begitu, perbedaan penelitian ini dengan penelitian sebelumnya yakni lebih kepada praktik fraud (kecurangan) pada sektor politik yang melibatkan elit partai politik.

Dengan demikian, artikel ini kemudian mengajak kepada pertanyaan, bagaimana peran akuntansi forensik dalam mendeteksi dan mencegah praktik korupsi politik. Batasan dalam artikel ini hanya seputar peran dan implikasi akuntansi forensik dalam upaya mendeteksi dan mencegah pemberantasan korupsi politik.

\section{B. TEORI (Literature Review)}

Seiring meningkatnya praktik kecurangan (fraud) di berbagai sektor telah membuat teori fraud (kecurangan) mengalami perkembangan. Hal ini yang melahirkan teori fraud pentagon. Teori ini dikembangkan oleh Crowe Horwart (2012). Teori ini merupakan pengembangan dari teoriteori sebelumnya. Seperti Fraud triangle oleh Cressey (1953) dan fraud diamond yang dikembangkan oleh Wolfe dan Hermanson. Dengan kata lain seiring perkembangan keilmuan, teori fraud pentagon mengalami beberapa penambahan elemen-elemen yang sangat berpengaruh terhadap kecurangan (fraud). 
Tabel 1. Perubahan Teori Fraud Pentagon

\begin{tabular}{cccc}
\hline Teori & Fraud Triangle & Fraud Diamond & Fraud Pentagon \\
\hline \multirow{3}{*}{ Elemen } & Opportunity & Opportunity & Opportunity \\
\cline { 2 - 4 } & Pressure & Pressure & Pressure \\
\cline { 2 - 4 } & Rasionalization & Rasionalization & Rasionalization \\
\cline { 2 - 4 } & & Capability & Competence \\
\hline Sumber & Cressey (1953) & Wolfe dan & Arrogance \\
& & Hermanson (2004) & \\
& &
\end{tabular}

Sumber : diolah peneliti

Dari tabel perubahan teori fraud pentagon, dapat digambarkan semua elemen-elemen yang terdapat dalam teori fraud pentagon maka bisa dijelaskan secara rinci sebagai berikut;

Pertama, Opportunity (Peluang). Peluang merupakan kesempatan yang terbuka untuk melakukan kecurangan dengan dibuktikan oleh minimnya pengendalian internal. Peluang ini seringkali menjadi salah satu elemen utama bagi seseorang untuk melakukan fraud. Contoh; bila di era digital, pencatatan keuangan partai politik masih banyak menggunakan pencatatan secara manual. Padahal era revolusi industri 4.0 sudah harus menggunakan pencatatan digital, sehingga dengan begitu, penerimaan sumbangan baik dari kader, simpatisan dan pengurus tentu sulit dicatat dengan baik. Eksesnya akan sangat rentan terhadap manipulasi pencatatan data keuangan.

Kedua, Pressure (Tekanan). Tekanan merupakan desakan yang menjadi niat utama seseorang untuk melakukan dan menyembunyikan kecurangan. Dalam konteks ini ada beberapa bentuk tekanan yang timbul

baik dari internal maupun eksternal pelaku. Contoh; kesulitan ekonomi atau kebutuhan keuangan untuk pencalonan dalam kontestasi elektoral yang merupakan bentuk tekanan internal. Sedangkan bentuk eksternal berasal dari tekanan pihak luar untuk mendorong pelaku melakukan kecurangan. Seperti kebutuhan yang tinggi bagi operasional partai politik membuat banyak politisi yang merupakan pengurus partai politik melakukan cara lain untuk mendapatkan dana operasional. Ketiga, (Rasionalisasi). merupakan pembenaran yang dilakukan oleh para pelaku dalam melakukan kecurangan (fraud). Biasanya para pelaku akan memiliki argumentasi yang menurutnya logis dan rasional ketika melakukan kecurangan. Contoh; politisi atau pengurus partai politik yang melakukan suap dengan tujuan untuk memperlancar atau sebagai ucapan terima kasih kepada pihak lain yang berhasil meloloskan tindakan proyek yang terindikasi korupsi. 
Keempat,

Competence

(Kompetensi). Kompetensi merupakan segala kemampuan dan kapabilitas yang dimiliki seseorang dalam upaya melakukan kecurangan. Biasanya kompetensi ini dimiliki secara personal yang kemudian digunakan untuk kepentingan pribadi. Contoh; kuasa yang dimiliki oleh kader partai politik dalam sebuah kebijakan membuat celah korupsi semakin terbuka lebar.

Kelima, Arogance (Arogansi). Arogansi merupakan sikap superioritas atas hak atau keserakahan dari seseorang yang menilai bahwa pengendalian internal tidak perlu berlaku pada dirinya sendiri. Contoh; seorang presiden ataupun ketua umum partai politik yang tidak ingin diberlakukan fungsi pengawasan terhadap dirinya sendiri.

Lebih lanjut definisi fraud merupakan suatu pengertian secara umum dan mencakup beragam cara yang dapat digunakan untuk mendapatkan keuntungan dari orang lain melalui berbagai perbuatan yang tidak benar. Meski begitu, tidak ada definisi atau aturan yang dapat digunakan sebagai suatu pengertian secara umum dalam mengartikan fraud yang meliputi cara yang mengandung sifat mendadak, menipu, cerdik dan tidak jujur yang digunakan untuk mengelabuhi seeorang. Satu-satunya batasan untuk mengetahui pengertian di atas adalah yang membatasi sifat ketidakjujuran manusia (Albrecht et al, 2012)

Definisi fraud juga dipertegas oleh Association of Certified Fraud Examiner (ACFE) dalam Fraud
Examiners Manual yang menjelaskan bahwa fraud (kecurangan) berkenaan dengan adanya keuntungan yang diperoleh seseorang dengan menghadirkan sesuatu yang tidak sesuai dengan keadaan yang sebenarnya. Di dalamnya termasuk unsur-unsur surprise atau tidak terduga, tipu daya, dan tidak jujur yang bisa merugikan orang lain. Sedangkan studi Balogna dan Lindquist (1953) dalam Fraud Auditing and Accounting Forensic menyatakan bahwa fraud adalah penipuan yang disengaja dan umumnya diterangkan sebagai kebohongan, penjiplakan dan pencurian. Fraud dapat dilakukan terhadap pelanggan, kreditor, pemasok, banker, investor, penjamin asuransi dan pemerintah. Dengan berdasarkan berbagai rujukan tersebut maka fraud (kecurangan) dapat diistilahkan sebagai bentuk kecurangan yang mengandung makna penyimpangan dan perbuatan melanggar hukum (illegal act) yang dilakukan dengan sengaja untuk tujuan tertentu. Seperti untuk menipu atau memberikan gambaran keliru (mislead) kepada pihak-pihak lain yang dilakukan oleh orang-orang baik dari dalam maupun dari luar organisasi.

\section{METODE PENELITIAN}

Metode Penelitian ini mengunakan pendekatan kualitatif dengan objek penelitian pada beberapa kasus korupsi politik yang melibatkan elit Partai Keadilan Sejahtera, Partai Persatuan Pembangunan, Partai Golkar dan Partai Demokrat. Adapun untuk mengukur validitas penelitian, peneliti 
menggunakan metode kepustakaan (library research) dalam mengelaborasi berbagai macam literatur baik berupa buku, jurnal, maupun literatur yang relevan dengan tema tulisan. Metode kepustakaan ini dipilih agar dapat memadukan hasil temuan bertema sama sebagai kajian terdahulu dan kajian kekinian (Zed, 2008). Dengan begitu, adanya konfirmasi atas kajian terdahulu bisa menemukan unsur kebaruan (novelty) dalam penelitian selanjutnya dengan tema sejanis.

\section{HASIL DAN PEMBAHASAN}

\section{Akuntansi Forensik dan Korupsi Politik}

Partai politik menjadi sebuah organisasi yang sangat rawan dengan praktik korupsi. Apalagi tingginya biaya operasional sebuah partai politik agar tetap eksis dalam kancah politik nasional, membuat partai politik membutuhkan biaya politik yang cukup besar dalam setiap kontestasi politik. Bahkan seorang calon anggota legislatif saja untuk berkonstestasi dalam Pemilu legislatif setingkat DPR RI saja membutuhkan biaya berkisar 12 miliar untuk setiap daerah pemilihan. Gejala tersebut menunjukan bahwa adanya kecenderungan pragmatisme politik dalam merebut dukungan konstituen yaitu adanya hambatan pendanaan yang dijadikan pendukung utama kampanye politik. Selain itu, menguatnya ideologi pasar, melemahnya ideologi partai, menonjolnya politik kemasan yang bertumpu pada pencitraan dan individualisasi perjuangan politik. Artinya ditemukan motivasi berlapis dari para legislator yaitu motif utama pada kekuasaan dan kepentingan ekonomi serta beberapa motif turunan (Wibowo, 2013)

Motivasi ini yang menyebabkan para kader partai politik seolah menjadi pemburu rente ekonomi yang kemudian berdampak pada menurunya elektabilitas partai di hadapan publik. Sebut saja, sejumlah elit partai politik semenjak era reformasi telah terlibat korupsi politik. Seperti, Ketua Umum Partai Demokrat, Presiden Partai Keadilan Sejahtera, Ketua Umum Partai Golkar. Telah membuat kepercayaan publik terhadap beberapa partai politik tersebut semakin menurun. Untuk kasus beberapa partai politik tersebut, modus utama yang dilakukan oleh semua elit partai politik adalah korupsi suap.

Sejatinya untuk menekan korupsi politik telah banyak gagasan agar partai politik bisa lebih mandiri ketimbang mengantungkan sumbersumber dana diluar partai. Selama ini pendanaan partai politik telah jelas diatur dalam undang-undang, namun masih saja belum mampu mengedepankan aspek transparansi yang dapat diakses oleh publik. Semisalnya, usulan sayap bisnis sebenarnya ditujukan untuk membangun jiwa kewirausahaan ditubuh partai politik. Disini diasumsikan bahwa partai politik bukan semata-mata lembaga politik, akan tetapi telah berevolusi menjadi sebuah lembaga bisnis. Harapannya, dengan mengelola lembaga bisnis sendiri, maka pengurus dan kader 
partai politik dapat memiliki kesibukan baru yakni berbisnis-berpolitik.

Tetapi bisa disimpulkan, banyak pihak yang tidak sependapat partai politik memiliki sayap bisnis. Sebab motivasi utama orang berpartai akan bergeser ke motivasi bisnis. Partai politik, pada akhirnya tidak lagi dipandang sebagai tempat pengabdian, tetapi telah bergeser menjadi lahan mencari pekerjaan. Artinya usulan sayap bisnis banyak ditolak karena akan membuat orang bergabung dalam sebuah partai berdasarkan kepentingan bisnis dan bukan motif persamaan ideologi semata. Kalau kultur dan logika partai sebagai lembaga politik telah bergeser pada kultur dan logika bisnis, maka akan muncul dilema baru. Akhirnya kedepan makin banyak partai politik yang didirikan dengan logika bisnis (Alfian, 2009).

Pada praktiknya pendanaan partai tidak dapat menggantungkan semata-mata pada iuran anggota yang membuktikan bahwa tidak ada satupun partai politik di Indonesia yang dapat menjalankan operasionalnya hanya dari iuran anggota. Bahkan untuk keperluan mengikuti ajang kontestasi politik elektoral, sudah dipastikan akan banyak partai politik yang bergantung pada perolehan sumbangan. Sumbangan pihak lain merupakan salah satu sarana bagi memenuhi pundi-pundi pendanaan partai politik. Melihat kenyataan ini tentulah kemungkinan adanya fraud (kecurangan) yang dilakukan oleh kader partai plitik akan semakin besar.
Sebab, partai politik butuh dana operasional yang berasal dari kader yang sukses dalam menapaki karir politik.

Disinilah kemudian peran akuntansi forensik harus bisa ikut mendeteksi dini kecenderungan terjadinya fraud (kecurangan). Perlu diketahui bahwa profesi akuntansi forensik di Indonesia semakin berkembang sejak adanya krisis moneter 1997. Terutama dalam sektor publik yang memang memiliki angka kecederungan yang tinggi terhadap berbagai kecurangan (fraud) seperti korupsi dan suap. Bila ditelisik akuntansi forensik dan audit forensik memiliki makna yang sama. Audit forensik tentu berbeda dengan audit umum, karena audit umum harus memberikan opini audit, sedangkan audit forensik tidak ditujukan untuk memberikan opini audit. Dengan begitu akuntansi forensik merupakan profesi baru dalam audit kecurangan. Akuntan forensik lahir dari tanggung jawab fraud auditor untuk melakukan investigasi terhadap kasus di sekitar masalah keuangan yang mengarah pada konsekuensi hukum (Karyono, 2013).

Dalam praktiknya akuntansi forensik meliputi bidang yang lebih luas seperti (1) dalam penyelesaian sengketa antar individu (2) di perusahaan swasta dengan berbagai bentuk hukum, perusahaan tertutup maupun yang memperdagangkan saham atau obligasinya di bursa, joint ventura, special purposes companies (3) diperusahaan yang sebagian atau seluruh sahamnya dimiliki negara, baik 
di pusat maupun daerah (BUMN/BUMND) dan terakhir didepartemen/kementerian

pemerintah pusat dan daerah, MPR, DPR/DPRD dan lembaga-lembaga negara lainnya (Tuanakota, 2016).

Selain itu seorang akuntan atau auditor forensik selain memiliki keterampilan akuntansi, juga membutuhkan pengetahuan tambahan terutama dalam ilmu hukum, psikologi, teknologi informasi, komunikasi yang digunakan untuk membantu analisis investigasi. Hal itu dilandasi dari fungsi dasar dari akuntansi forensik yang bertugas memberikan bukti nyata terutama dimuka pengadilan terhadap berbagai tindak kejahatan. Dimana dalam konteks audit forensik terlebih didahului oleh audit investigasi terhadap sebuah tindak kriminal hingga kemudian menjadi saksi ahli di pengadilan. Meski demikian dalam prosesnya audit forensik bersifat proaktif dan reaktif. Proaktif artinya digunakan untuk mendeteksi kemungkinan-kemungkinan resiko terjadinya fraud atau kecurangan. Sedangkan reaktif, artinya audit yang dilakukan ketika ada indikasi (bukti) awal terjadinya fraud. Sehingga audit khusus atau penunjukan khusus ini akan menghasilan beberapa sinyal ketidakberesan. Dengan catatan, audit forensik dalam hal ini melakukan investigasi secara mendalam.

Selain itu akuntansi forensik atau audit forensik merupakan penerapan disiplin ilmu akuntansi dalam arti luas. Terutama auditing pada masalah hukum untuk penyelesaian di dalam atau di luar pengadilan baik disektor publik maupun privat. Sedangkan menurut Bologna dan Linquist (1995) audit forensik merupakan penerapan keterampilan keuangan dan mentalitas investigasi terhadap isu-isu yang belum terselesaikan yang dilakukan dalam konteks rules of evidence.

Identifikasi mengenai akuntansi forensik semakin menegaskan rekam jejak akuntansi forensik sebagai proses akuntansi hukum yang lebih mengedepankan investigasi dalam penyelesaian sebuah kasus kecurangan (fraud). Sehingga dengan demikian akuntansi forensik bisa merupakan perpaduan antara akuntansi, auditing, dan kemampuan investigasi yang kemudian menghasilkan kekhususan. Dengan begitu akuntansi forensik juga bisa diterapkan dalam upaya mendeteksi fraud (kecurangan) terutama praktik korupsi suap dalam ranah politik.

Dalam konteks korupsi politik, peran akuntansi forensik cukup banyak digunakan untuk membongkar berbagai kasus korupsi dan suap. Seperti, dalam kasus Bank Century, Badan Pemeriksa Keuangan (BPK) memulai penelusuran aliran dana talangan atau bailout Bank Century senilai $\operatorname{Rp} 6,7$ triliun dengan membentuk tim khusus audit forensik sebanyak 60 orang untuk penelusuran aliran dana ini (Kontan, 2011). Begitupun pada beberapa kasus korupsi politik yang telah melibatkan ketua umum Partai Demokrat, Partai Golkar, Partai Persatuan Pembangunan dan Partai Keadilan Sejahtera (PKS) tim audit forensik dibentuk untuk 
melakukan pelacakan terhadap indikasi fraud (kecurangan). Sebab, tanpa adanya tim audit forensik tentu akan sulit melakukan pelacakan terhadap indikasi fraud (kecurangan). Hal itu disebabkan tim audit forensik memiliki kemampuan dan akses khusus yang membuat pelacakan terhadap alat bukti lebih cepat. Apalagi dalam konteks korupsi politik, para pelaku tindak pidana korupsi suap, akan dengan canggih berupaya untuk menghilangkan alat bukti. Disinilah tim akuntansi forensik akan sangat dibutuhkan sebagai upaya melacak dan mengungkap suatu kecenderungan indikasi korupsi politik. Dengan demikian, dalam konteks partai politik, tim akuntansi forensik bisa dibentuk secara independen tanpa kepentingan apapun yang berasal dari internal maupun dari tim indenpenden dengan tujuan untuk melacak berbagai kemungkinan indikasi korupsi politik yang melibatkan para kader.

\section{Whistleblowing dan Akuntansi Forensik}

Perlu menjadi catatan bersama bahwa korupsi sebagian besar dilakukan oleh orang-orang yang memiliki kuasa dan berusaha menyelewengkan wewenang mereka demi kepentingan pribadi. Sebut saja kasus korupsi yang melibatkan Djoko Susilo sebagai aparat hukum negara untuk memperlancar tender pengadaan simulator SIM. Hal ini menunjukkan adanya penyalahgunaan wewenang oleh pejabat tinggi dan terjadi suap terhadap penjabat tinggi. Selain itu, Djoko Susilo terbukti melakukan pencucian uang dengan menyamarkan, menyembunyikan, atau mengaburkan kepemilikan harta kekayaannya yang diperoleh dari kasus korupsi ini. Dengan demikian, peran akuntan forensik sangat dibutuhkan sebagai penyelidikan guna mengumpulkan barang bukti mampu membawa kasus-kasus korupsi ke pengadilan. Dengan adanya bukti-bukti yang kuat maka jaksa mampu menuntut tersangka korupsi dengan hukuman yang sesuai. Meski begitu untuk mengumpulkan temuan dan alat bukti yang akurat harus dibangun saluran sistem pelaporan dari publik sehingga tim audit bisa menerima banyak masukan yaitu saluran whistleblowing.

Dalam konteks partai politik, tentu dapat menerapkan penggunaan teori yang ada dalam akuntansi forensik dalam pengelolaan dan manajemen keuangan partai. Seperti dengan membangun saluran whistleblowing dalam tubuh partai politik. Saluran ini bertujuan untuk mendeteksi dan menekan terjadinya korupsi politik yang melibatkan kader partai. Artinya, pemanfaatan akuntansi forensik bisa digunakan dalam mencegah terjadinya fraud (kecurangan) dan mendeteksi praktik korupsi politik dalam partai politik. Sebab, meskipun dilakukan pengendalian internal yang sistematis, akan tetapi celah atau peluang untuk melakukan fraud (kecurangan) tetap terbuka.

Celah inilah yang dapat menjadi ancaman nyata bagi semakin banyaknya kader partai yang terlibat dalam korupsi politik. Dengan kuasa 
yang kuat bisa dipastikan elit partai politik yang memiliki karakter pemburu rente bisa memanfaatkan kekuasaan yang dimiliki untuk kepentingan pribadi. Hal itu mengonfirmasi bahwa kecenderungan seseorang melakukan fraud dikarenakan; Pressure (tekanan), Opportunity (peluang), Rationalization (Rasionalisasi), Comptence/capability (kompetensi) dan Arrogance (arogansi). Dari beberapa faktor tersebut, tentu langkah preventif selain pengendalian internal bisa diterapkan untuk menekan terjadinya korupsi politik. Salah satu alternatif dalam pengendalian internal tersebut adalah penerapan teori akuntansi forensik dalam pengelolaan keuangan partai politik. Bila kemudian terdengar ada gejala korupsi politik, maka partai politik bisa membuat tim khusus audit forensik untuk melakukan audit investigasi dalam kasus tersebut.

Selain itu, penerapan akuntansi forensik dalam pengelolaan keuangan partai politik sejatinya dengan membangun saluran whistleblowing. Sebab saluran whistleblowing yang merupakan bagian dari akuntansi forensik telah dapat memainkan peran penting dalam lingkungan kontrol internal organisasi dan auditor internal (Read \& Rama, 2003). Dengan whistleblowing dapat mendorong setiap individu yang berani secara diam-diam untuk dapat melaporkan kemungkinan kecurangan, aktivitas yang tidak jujur atau kecurangan lain yang dilakukan oleh elit partai politik. Meski pada kenyataannya para whistleblower akan mencari perlindungan dari tindakan semenamena atau terdampak konsekuensi buruk karena telah melaporkan kecurangan.

Oleh sebab itu diperlukan hotline khusus untuk whistleblower sebagai infrastruktur dasar yang dibutuhkan untuk mendorong orang-orang berani melaporkan segala bentuk fraud (kecurangan). Salah satu alternatif penerapan whistleblowing adalah dengan menggunakan kotak saran anonim. Dengan kotak saran anonim ini setiap whistleblower akan berani melaporkan terjadinya kecurangan. Selain itu, sistem pelaporan whistleblowing juga diusulkan menggunakan saluran media sosial. Dikarenakan media sosial saat ini sangat banyak digunakan oleh masyarakat untuk saluran informasi keseharian. Meski studi lanjutan tentang pemanfaatan media sosial untuk whistleblowing memang belum banyak ditemukan.

Dengan kata lain, peran akuntansi forensik dalam partai politik adalah mendorong penggunaan sistem whistleblowing untuk mendeteksi segala kemungkinan kecurangan (fraud) yang dilakukan oleh kader partai. Saluran whistleblowing ini diharapkan bisa mudah diakses oleh publik sehingga publik tidak enggan untuk melaporkan segala kecurangan yang telah dilakukan oleh elit partai politik. Dengan saluran ini akan bisa mendorong publik untuk aktif berpartisipasi memberikan pelaporan bila menemui indikasi fraud (kecurangan) yang dilakukan oleh elit 
maupun kader partai politik di sekitarnya. Partisipasi aktif ini sangat mungkin tumbuh dengan baik mengingat Indonesia masih sangat kuat kultur voluntarisme atau sifat kerelawananya. Dalam beberapa kajian fenomena relawan politik diketahui bahwa peran partisipasi publik banyak memberikan kontribusi nyata bagi upaya mengawal dan mengawasi proses jalanya demokrasi politik di Indonesia, Arianto, 2014; 2019).

Artinya, melalui penerapan saluran whsitleblowing, posisi akuntansi forensik telah ikut berperan untuk melacak indikasi fraud (kecurangan) yang melibatkan kader partai politik. Dengan demikian bila skema dari akuntansi forensik yaitu membangun saluran whistleblowing telah dibangun oleh partai politik, maka dampaknya akan dapat membangun pemahaman kader dan elit partai politik untuk bisa mengedepankan literasi anti-fraud. Sekaligus bisa mendorong upaya membangun program literasi anti fraud dalam partai politik.

Meski demikian untuk memupuk literasi anti fraud para pengurus partai politik juga harus mengikuti serangkain pelatihan akuntansi forensik terutama dalam proses pencegahan korupsi politik melalui whistleblowing. Dengan berbagai langkah taktis tersebut akan terbangun kultur anti fraud yang bisa mendidik kader partai dan elit partai politik untuk tidak melakukan berbagai bentuk fraud (kecurangan) seperti memberi suap dan terlibat dalam korupsi politik. Dengan begitu, peran akuntansi forensik melalui saluran whistleblowing bisa melahirkan literasi anti fraud (kecurangan) dalam partai politik. Sekaligus melahirkan budaya baru yang lebih mengedepankan etika dalam upaya memberangus segala bentuk korupsi politik.

\section{E. SIMPULAN DAN SARAN}

1. Simpulan

Korupsi politik merupakan salah satu bentuk fraud (kecurangan) yang harus dicegah sedini mungkin. Pencegahan tersebut bisa melalui saluran whistleblowing sebagai bagian dari akuntansi forensik. Sebab kunci deteksi dari akuntansi forensik terletak pada berfungsinya saluran whistleblowing dalam mencari berbagai bukti kecurangan. Dalam berbagai kasus korupsi politik yang melibatkan Ketua Umum Partai Keadilan Sejahtera, Partai Demokrat, Partai Golkar dan Partai Persatuan Pembangunan, peran tim audit forensik memegang peranan utama dalam mencari bukti, dan investigasi atas dugaan tersebut. Hal itu disebabkan akuntansi forensik memiliki sifat kekhususan dalam menangani sebuah kasus fraud (kecurangan). Melalui saluran whistleblowing, semua alat bukti kecurangan bisa dilacak dan dideteksi secara dini oleh para tim auditor forensik. Meski begitu, saluran whistleblowing juga harus dibangun agar lebih partisipatif seperti dengan menggunakan kanal media sosial.

Pada akhirnya, definisi akuntansi forensik merupakan suatu 
skema yang dikembangkan sebagai strategi deteksi melalui tindakan persuasif dan preventif dengan penerapan prosedur audit investigasi yang bersifat ligitasi untuk menghasilkan berbagai temuan dan alat bukti adanya indikasi fraud (kecurangan). Sehingga berbagai temuan dan alat bukti tersebut bisa digunakan dalam proses pengambilan keputusan di pengadilan. Dengan demikian dapat disimpulkan bahwa akuntansi forensik sebagai akuntansi khusus yang telah berkontribusi secara positif dalam upaya mendeteksi, mencegah dan ikut memberantas berbagai praktik korupsi politik di Indonesia. Selain itu, peran akuntansi forensik dalam upaya pencegahan berbagai bentuk fraud (kecurangan) juga terbukti dapat membangun literasi anti fraud dalam partai politik.

\section{Saran}

Penelitian ini menggunakan metode kualitatif dengan pendekatan studi pustaka sehingga hanya berdasarkan literatur dan kajian dari penelitian terdahulu. Keterbatasan penelitian ini hanya dielaborasi dengan metode studi kepustakaan dengan fokus pada korupsi politik semata yang melibatkan beberapa partai politik. Oleh sebab itu diharapkan kedepan akan banyak penelitian serupa yang mengulas peran akuntansi forensik dalam pemberantasan korupsi politik baik secara kuantitatif maupun kualitatif dengan mengunakan data primer. Dengan demikian, penelitian kedepan bisa mengelaborasi lebih luas kajian ini dengan menggunakan metode kuantitatif maupun kualitatif mengenai pengaruh akuntansi forensik dalam mendeteksi korupsi politik yang melibatkan partai politik.

\section{DAFTAR PUSTAKA}

ACFE. INC. (2018). Report to the Nations: Global Study On Occupational Fraud and Abuse. Association of Certified Fraud Examiner, Inc

ACFE. (2018). Survai Fraud Indonesia 2016. Association of Certified Fraud Examiner Indonesia Chpater.

Albrecht, et al. (2012). Fraud Examination ( $4^{\text {th }}$ Edution). USA : South-Western.

Alfian, M. A. (2009). Demorkasi Pilihlah

Aku (Warna-Warni Politik kita). Trans Publishing, Malang.

Arianto, B. (2014). Fenomena Relawan Politik dalam Kontestasi Presidensial 2014. Jurnal Ilmu Sosial dan Ilmu Politik UGM. Volume 18, No 2, November (146162)

(2019). Antara Relawan

Teman Ahok dan Partai Politik Kontestasi Pemilihan Kepala Daerah DKI Jakarta 2017. Journal of Social Politics and Governance, 1(1), 55-79.

Bologna G. \& Robert. (1995). Fraud Auditing and Forensic Accounting, Tool and Techniques, 2th. Edition. New York : Jhon Wiley.

Claudia, G. (2018). Akuntansi Forensik untuk Bedah Kasus Korupsi. JEMAP : Jurnal Ekonomi, Manajemen, Akuntansi dan Perpajakan. Vol. 1, (1), 95.

Cressey, D.R. (1953). Other People's Money : A Study in the Social Psyvhology of Embezzlement. Glencoe, IL : FreePress. 
Daurrohmah, E. W., \& Urumsah, D (2018). Efektivitas Audit Forensik dalam Mendeteksi Suap dengan Dukungan Whistleblowing. Tesis. Universitas Islam Indonesia.

Enofe, A. O. et al. (2013). The Impact of Forensic Accounting on Fraud Detection. European Jorunal of Businees and Management, 5 (26), 61-73

Girling, J. D et al. (1997). Corruption, capitalism and democracy (Vol. 4). Psychology Press.

Gumelar, M. (2019). The Connectivity of Whistleblowing Online System Between Government Agencies in Indonesia : A New Roudn of Preventing and Eradicating Corruption. Asia Pacific Fraud Journal, 4(2).

Horwath, C. (2012). Why the Fraud Triangle is no Longer Enough. In Horwath, Crowe LLP.

Karyono. (2013). Forensic Fraud. Yogyakarta: Penerbit Andi

Kompas.com. (2019). KPK akan Bentuk Unit akuntansi Forensik. (Online). https://kompas.id/baca/utama/201 9/08/07/kpk-akan-bentuk-unitakuntansi-forensik/ diakses 10 Janurari 2020. .(2019). ICW : Kerugian Negara Akibat Korupsi Capai 929 Triliun. Diakses 11 Agustus 2019. https://nasional.kompas.com/rea d/2019/04/28/15294381/icwkerugian-negara-akibat-korupsipada-2018-capai-rp-929-

triliun?page $=$ all,

Kontan.com. (2011). BPK Sudah Bentuk Tim Audit Forensik Telusuri Bailout Bank Century.
(Online). https://nasional.kontan.co.id/ne ws/bpk-sudah-bentuk-tim-auditforensik-telusuri-bailout-bankcentury-diakses 10 Maret 2020.

Mamahit, A.I., \& Urumsah, D. (2018). The Comprehensive Model of Whistleblowing, Forensic Audit, Audit Investigation, and Fraud Detection. Journal of Acoounting and Strategic Finance, I (2), 153-162.

Near, J. P., \& Miceli, M. P. (1995). Effective-whistle blowing. Academy of management review, 20(3), 679-708.

Read, W. J., \& Rama, D. V. (2003). Whistle-blowing to internal auditors. Managerial Auditing Journal.

Syahputra, B. E., \& Urumsah, D. (2019). Deteksi Fraud Melalui Audit Pemeritnahan yang Efektif; Analisis Multi Grup Gender dan Pengalaman. Jurnal Akuntansi dan Bisnis, 19 (1), 31-42.

Tuanakotta, T. M (2016). Akuntansi Forensik dan Audit Investigatif (Edisi ke-2. Jakarta Salemba Empat.

Quah, J.ST. (2013). Curbing Corruption in Asian Countries. ISEAS. Emerald Publishing

Wardhani, A.K \& Urumsah, D. (2018). Peran Whistliblowing dalam Praperencanaan dan Pelaksanan Pemeriksaan Investigatif untuk Mendeteksi Fraud di Indonesia. Tesis, Universitas Islam Indonesia

Wibowo, PA. (2013). Mahalanya Demokrasi Memudarnya Ideologi, Potret Komunikasi Politik legislator Konstituen. Jakarta. Penerbit Kompas. 
Vol.2 No.1 Juni 2020

Wiratmaja, I.D.N. (2010). Akuntansi Forensik dalam Upaya Pemberantasan Tindak Pidana Korupsi. Jurnal Ilmiah Akuntansi dan Bisnis, 5 (2).

Zed, M. (2008). Metode Penelitian Kepustakaan, Cetakan 1. Jakarta: Yayasan Obor Indonesia. 